TranscUlturAl, vol. 11.1 (2019), 145-146

https://journals.library.ualberta.ca/tc/index.php/tc

\title{
Teaching Translation: Programs, Courses, Pedagogies, edited by Lawrence Venuti. Routledge, 2017, 259 pages.
}

\author{
Jennifer Quist \\ University of Alberta
}

Lawrence Venuti adds a dedicated work on pedagogy to his already expansive bibliography with 2017's Teaching Translation: Programs, Courses, Pedagogies. An edited collection of short articles contributed by translation studies educators, most of whom work in the United States, the book reads less like a critical or prescriptive treatment of what formal post-secondary teaching of translation studies ought to be and more like a revelation of what teaching in the field is and what it has the potential to become in the near future. By Venuti's count, in the past fifty years, the number of translation education programs has grown to over 350 worldwide. The book draws on professionals from twenty-six of these programs, curating articles which tend to read more as practical reports on applied pedagogy rather than critical essays. As directed by a list of prompts, which can be found near the end of the book's introduction, contributors detail where translation is taught, who is studying it, with what materials, at what levels, how, and to what ends. Underlying theoretical premises are mentioned but the greater balance of the chapters is given to descriptions of the institutional conditions: programs' terms of reference, including basic definitions of what is meant by translation; descriptions of student subscribers before, during, and after participation in the programs; recommendations of teaching resources and strategies; and other professional observations, assumption, and advice. Because the chapters are written in response to a single list of questions, they have a sameness, which is at once sound research methodology, a useful tool, but also a bit of a pedestrian reading experience. Unlike much of Venuti's previous work, the objective of this book is not stirring rhetorical calls for action but "to take stock of how translation studies is taught at the present time" and to bring forward creative and innovative projects and pedagogical practices in a field, which by now "has achieved such stability as might resist change in order to maintain a viable institutional position" (2). The book invokes a pause wherein to document current translation teaching and explore how teaching can be improved now that the legitimacy of translation studies has reached a high water mark in teaching institutions, and has become at risk of calcifying into something that resists growth and development. This kind of institutional hardening would be particularly troubling in a field like translation where what we do is also "a fact of daily life" (1) —ever evolving, ever changing daily life that must remain organic and supple. Whether one accepts Venuti's characterization of this moment in translation studies teaching or not, the book succeeds as a well-organized, clear, and insightful reference for teachers and researchers looking to compare and contrast contemporary methods, materials, and results across a broad sample of English-oriented translation studies programmes.

This work is licensed under a Creative Commons Attribution 3.0 License 
TranscUlturAl, vol. 11.1 (2019), 145-146

https://journals.library.ualberta.ca/tc/index.php/tc

The collection is meant to provide "exemplary models that can be replicated or adapted in other institutions" (13) and ranges widely throughout programs and approaches from undergraduate certificates to doctoral studies. The use of translation strictly as a second language learning exercise is not addressed in the book, and written translation is emphasized over interpretation. The books does not dismiss but does demarcate between the teaching of translation in language departments and the education of translation studies scholars in literatures, humanities, and social sciences. Fine arts programs are included, wherein literary translation is taught in settings analogous to traditional American writers' workshops. An explicit editorial decision is made not to cordon the technical and pragmatic aspects of translation studies from the humanistic aspects of the field (13). Interdisciplinarity's status as a watchword of translation studies and is preserved and promoted here.

Organized methodologically rather than according to language pairings or national affiliations, the book is a reflection of students who come to translation studies from varied backgrounds. Accordingly, most of the translation studies programs addressed in the book are not aligned along linguistic or national boundaries, a reality best met with programs and pedagogies that work through and with diversity rather than against it. This ideal of interfering with English hegemony in favour of linguistic diversity is one of the book's refrains. Having said so, however, a working classroom requires common linguistic ground on which teachers and students can meet, and in this collection, that common ground is always English. Indeed, among the book's grounding assumptions, Venuti explains that "English has become the lingua franca of the international community of translation scholars" (12). If there is any doubt about the centrality of English, statements like these in books meant to shape translation studies as it becomes standardized as an academic endeavour will surely help to preclude any doubt. It is an irony that underlies the premise of the book, and was perhaps implied when Venuti wrote, as the author of The Invisibility of the Translator, that translators "can interrogate and change the academic status quo, but they need to be able to engage in current scholarly debates" (277). That this conclusion may be inevitable does not make it any less disheartening. 